a l-iltizam , Vol.3, No.2, November 2018

\title{
KONTRIBUSI AL-QUR'AN DALAM MENGEMBANGKAN PEMBELAJARAN AKTIF (ACTIVE LEARNING) DI LEMBAGA PENDIDKAN
}

\author{
Oleh: Karman \\ FTK/Pascasarjana UIN SGD Bandung, Email: karmanfaiz@uinsgd.ac.id
}

\begin{abstract}
The Qur'an as a "silent book" when invited to dialogue produces important principles in learning, such as the principle of the use of the drill method. The drill method in learning has been understood as a supporter of behavioristic theory. This paper aims to explain the contribution of the Qur'an in the development of active learning, especially the drill method. The method used to analyze this paper is a thematic interpretation with a multidisciplinary approach. The results of the analysis show that the drill method offered by the Qur'an is oriented towards students. This learning supports the humanistic and constructivist theories developed in educational institutions. The Qur'an can be said to have contributed theoretically and practically to inquiry learning development (group work), discovery, and self-direct-learning (independent learning). The drill method can build students' creativity and innovation.
\end{abstract}

Al-Qur'an sebagai "kitab bisu" ketika diajak berdialog menghasilkan prinsipprinsip penting dalam pembelajaran, seperti prinsip pengguna-an metode drill. Metode drill dalam pembelajaran selama ini dipahami sebagai pendukung teori behavioristik. Tulisan ini bertujuan menjelas-kan konribusi al-Qur'an dalam pengembangan pembelajaan aktif, terutama metode drill. Metode yang digunakan untuk menganalisis tulisan ini tafsir tematik dengan pendekatan multidisipliner. Hasil analisis menunjukkan metode drill yang ditawarkan alQur'an ber-orientasi pada peserta didik. Pembelajaran ini mendukung teori huma-nistik dan konstruktivistik yang dikembangkan di lembaga pendidikan. Al-Qur'an dapat dikatakan telah berkontribusi secara teoretis dan praktis bagi pengembangan belajar inquiri (kerja keompok), discovery (penemuan), dan self-direct-learning (belajar mandiri). Metode drill dapat membangun kreativitas dan inovasi peserta didik.

Keywords: strategi pembelajaran, konstruktivistik, inquiry, discovery.

\section{Pendahuluan}

Al-Qur'an mengidentifikasi dirinya sebagai manual book, buku petunjuk bagi manusia berkualitas (Qs. al-Baqarah/2:2). Klausa zâlika al-kitâb lâ rayba fîh hudan li al-muttaqîn merupakan penegasan AlQur'an sebagai pedoman dalam berbagai hal yang dibutuhkan manusia 
a l-iltizam , Vol.3, No.2, November 2018

dalam kehidupannya. |Al-Qur'an, sebagai kitab keagamaan, isi kandungannya telah menginspirasi berbagai aspek kehidupan manusia. AlQur'an bukanlah kitab sains, ilmu (pengetahuan) dan filsafat, tetapi di dalamnya ditemukan bahasan tentang persoalan ilmu (pengetahuan) dan filsafat. Al-Qur'am berbicara sekaligus menjawab persoalan-persoalan tentang Allah, dunia ruh individu, kebaikan dan keburukan, kebebasan berkehendak (free will), hidup dan mati, dan semacamnya. Ia juga menyoroti konsep-konsep mengenai yang "fenomena" dan "hakikat", asal-usul dan nasib manusia, ruang dan waktu, ketetapan dan perubahan, kekekalan dan keabadian, dan sebagainya. (Rida, 1960:107108; Cawidu, 1998:3-5).

Al-Qur'an, walaupun mengandung berbagai ragam masalah, tetapi tidak selalu tersusun secara sistematis seperti buku hasil ilmu (pengetahuan) karya manusia. Al-Qur'an dalam konteks ini dipandang sebagai kitab yang tidak sistematis dilihat dari sudut pandang metodologi ilmiah. Kondisi al-Qur'an seperti itu tidak mengurangi nilai alQur'an, sebaliknya, di situlah keunikan al-Qur'an sekaligus keistimewaannya. Al-Qur'an dengan kondisinya yang demikian menjadi objek kajian yang tidak akan kering oleh para cendekiawan dari berbagai kalangan sehingga ia tetap aktual sejak dinuzulkan. (Rida, 1960:107108). Al-Qur'an dengan fungsinya sebagai manual book mampu mengupgrade manusia menjadi makhluk berkualitas, muttaqîn.

Upaya merealisasikan petunjuk-petunjuk al-Qur'an, meniscayakan diajaknya berdialog. Upaya mendialogkan al-Qur'an dengan realitas kehidupan manusia sebenarnya dapat dirujuk pada pandangan teologis kaum Muslim, al-Qur'an sâlihun fí kulli zamân wa makân, alQur'an senantiasa relevan untuk segala waktu dan tempat. Jargon ini 
menutut kaum Muslim dapat menafsirkan al-Qur'an sesuai dengan konteks sosio-historis yang dihadapinya dan selalu berubah.

Tema penting Al-Qur'an dalam membimbing manusia berkualitas berfokus pada pendidikan. Al-Qur'an, sebagaimana dikemukakan para ahli merupakan salah satu dari sumber ilmu (pengetahuan) dan kebudayaan. Kedudukan al-Qur'an ini mendorong para penafsir untuk melakukan ijtihad kreatif --- eksplorasi dan elaborasi ---- kandungan ayat-ayat al-Qur'an yang dapat dijadikan pijakan bagi pengembangan teori dan praktik pendidikan (Islam). Al-Qur'an senantiasa berbicara, secara langsung atau tidak langsung, mengenai hampir semua unsur kependidikan.(Shihab, 2006:332). Itulah alasan sebagian ahli menyebut Al-Qur'an sebagai kurikulum (al-manhaj) pendidikan (Islam). Metodologi pendidikan dan pembelajaran bagian dari pendidikan yang dijelaskan Al-Qur'an. Namun, sesuai karakteristik Al-Qur'an yang tidak menjelaskan semua masalah secara detail, dialog intens mencari formula dan prinsip metodologi pendidikan dalam Al-Qur'an menjadi tantangan tersendiri.

Metodologi dalam konteks ini merupakan prosedur yang digunakan untuk mencapai tujuan pendidikan. (Kaplan, 1964:364; Tafsir, 1995:9). Metodologi pendidikan mencakup di dalamnya model, pendekatan, strategi, metode, dan teknik pendidikan. Metode drill salah satu metode pembelajaran yang biasa digunakan untuk mengaktifkan pembelajaran peserta didik. Namun, dalam implementasi pembelajaran, metode drill sering tidak dilaksanakan dengan optimal. Metode drill dipandang tepat hanya untuk menguji wilayah kognitif. (Kristen Ratenpao, 2017:54. Namun, menurut para ahli metode drill merupakan sebuah pembelajaran yang membantu peserta didik dalam memahami 
setiap langkah pegajaran yang ssuai elalui kebiasan yang diajarkan secara berulang. (Hamdani 2011; Roestiyah, 2008:125; dan Sagala, 2013:217). Menurut Karman (2017:217), metode drill dapat digunakan untuk pembelajaran akhlak sebagaimana yan ditunjukkan al-Qur'an.

Metode pembelajaran drill dilakukan dengan cara memberikan tugas kepada peserta didik secara berkelanjutan agar mereka tebiasa. Peserta didik secara tidak sadar telah membiasakan perilaku yang mulia dan memiliki daya kreativitas dan produktivitas yang profesional dan terampil dalam mengerjakan sesuatu. Hal ini akan mengakibatkan peserta didik setelah selesai melaksanakan pendidikan memiliki kompetensi dan kemampuan khusus yang dapat diandalkan. (Kusumawati \& Irwanto, 2016; Juniati, 2017). Al-Qur'an, menurut Karman, menunjukkan perannya dalam mengembangkan metode drill sebagaimana ampak dalam wahyu prtama melalui frasa iqra'. Frasa iqra' tersebut dapat diterjemahkan dengan "membaca reflektif". (Karman, 2017:1) Pendidikan dapat dilakukan dengan kegiatan pembelajran dalam arti penelitian, kajian, pengamatan dan obervasi, dan sederatan makna yang merefleksikan membangun kreativitas dan inovasi. Jika Al-Qur'an telah bersemangat membangun kreativitas dan inovasi pembelajaran, apa kontribusinya dalam mengembangkan metode pembelajaran aktif di lembaga-lembaga pendidikan?

Tulisan ini membatasi kajian pengembangan pembelajaran aktif terhadap metode $d r i l l$.

\section{Metode}

Sumber tulisan terdiri dari data primer dan data sekunder. Sumber data primer diambil dari Mushaf al-Qur'an. Sumber lainnya Mu'jam al-Mufahras li Alfâz Al-Qur'ân al-Karîm karya 'Abd al-Bâqî, Mu'jam 
a l-iltizam , Vol.3, No.2, November 2018

Mufradât fî̀ Alfâz Al-Qur'ân al-Karîm karya Râgib al-Isfahânî digunakan untuk pelacakan makna kata, kitab-kitab tafsir dan tulisan-tulisan tentang pendidikan yang dikemukakan para ahli pendidikan.

Pendekatan yang digunakan dalam tulisan ini interdisipliner. karena dalam realitasnya disiplin ilmu dapat berintegrasi-berinterkoneksi. (Karman dalam JPI, 2016:497-514). Langkah-langkah penulisan: (1) menetapkan tematik sebagai model tafsir yang digunakan, (2) menetapkan tema dan subtema kajian, (3) melacak ayat-ayat terkait dengan tema, (4) menganalisis tema-tema terkait, dan (5) menyusun simpulan.

\section{Metode Pembelajaran Drill dalam Al-Qur'an}

Al-Qur'an tidak mendefinisikan pembelajaran drill dalam seluruh ayatnya. Namun, merujuk pada pandangan para ahli tentang metode drill dalam pembelajaran, metodeini dianggap efektif untuk pembelajaran akhlak dan pembinaan sikap mental, telah diperkenalkan AlQur'an 15 abad yang lalu. Wahyu pertama yang sampai kepada Nabi Muhammad saw., secara eksplisit, telah mendorong manusia memahami pesan Tuhan melalui mtode drill. Frasa iqra', perintah 'membaca reflektif', (Mahmud Arif, 2015) mendeskripsikan dorongan Tuhan kepada manusia untuk membiasakan perilaku yang mulia, memiliki daya kreativitas dan produktivitas yang profesional dan terampil dalam mengerjakan sesuatu.

\section{Bentuk-bentuk Pembelajaran Drill}

1. Inkuiri, Inquiri (Kerja Kelompok)

Inkuiri dalam Kamus Webster's Encyclopedic Unabridge diartikan, ... a seeking for truth, information, or knowladge. An investigation 
as into an incident. Act of inquiry on seeking information by question. (Webster's Encyclopedic Unabridge, 1989:734) Inkuiri berarti proses bertanya dan mencari tahu jawaban terhadap pertanyaan ilmiah yang diajukan. Pertanyaan ilmiah merupakan pertanyaan yang dapat mengarahkan pada kegiatan penyelidikan terhadap objek pertanyaan. Ini berarti inkuiri merupakan proses memperoleh informasi dengan melakukan observasi atau eksperimen untuk mencari jawaban atau memecahkan masalah dengan bertanya dan mencari tahu. Pembelajaran inkuiri menekankan berpikir kritis untuk mencari dan menemukan sendiri jawaban dari suatu masalah yang dipertanyakan.

Al-Qur'an memberikan pedoman dalam membina sikap inkuiri ilmiah, antara lain pengetahuan yang ada di langit dan bumi akan diperoleh hanya dengan menggunakan alat teknologi, sultân, seperti tercantum dalam Qs. al-Rahmân/55:33. Orang-orang yang telah melakukan inkuiri berdasarkan ayat tersebut dapat menghasilkan teknologi kedirgantaraan. USA, misalnya, telah meluncurkan Apllo 11 untuk mendarat di bulan, sebagai wujud nyata dari kemajuan teknologi informasi, disusul dengan diluncurkan pesawat ulang alik Columbia, Challenger, dan Concord. Jauh sebelum itu, Uni Sovyet (Rusia) telah memiliki Lunik dan Soyuz.

Al-Qur'an juga mendorong manusia memerhatikan fenomena alam dan sosial secara kritis, sebagaimana tercantum dalam firman Allah Qs. Fusilat/41:53-54:

Kami akan memerlihatkan kepada mereka tanda-tanda (kekuasaan) Kami di segala wilayah bumi dan pada diri mereka sendiri, hingga jelas bagi mereka bahwa al-Quran itu benar. Tiadakah cukup bahwa Tuhanmu menjadi saksi atas segala sesuatu? Ingatlah bahwa mereka dalam 
a l-iltizam ,Vol.3, No.2, November 2018

keraguan tentang pertemuan dengan Tuhan mereka. Ingatlah bahwa Dia Maha meliputi segala sesuatu.

Kajian secara kritis-logis terhadap realitas alam semesta, al-âfâq yang dapat dilihat oleh manusia meliputi langit dibangun tanpa tiang, matahari dan bulan beredar di porosnya, akan menambah pengetahuan dan keimanan terhadap eksistensi sang pencipta. (al-Râzî, 1998:42; alMarâgî, 1998:10).

\section{Diskoveri, Discovery (Penemuan)}

Diskoveri merupakan proses mental yang mengharapkan pserta didik mampu mengasimilasikan suatu konsep atau prinsip. Proses mental tersebut antara lain: mengamati, mencerna, mengerti, mengelompokkan, membuat dugaan, menjelaskan, mengukur, membuat simpulan, dan sebagainya. Strategi pembelajaran diskoveri dilakukan dengan cara mengajar peserta didik secara terlibat dalam proses kegiatan mental melalui tukar pendapat, diksusi, seminar, dan mencoba sendiri agar peserta didik terbiasa dan dapat belajar sendiri.

Pendidik dalam discovery learning hendaknya memberikan kesempatan peserta didik untuk menjadi seorang problem solver, scientis, historian, atau ahli (expert). Bahan ajar tidak disajikan dalam bentuk akhir, tetapi peserta didik dituntut untuk melakukan berbagai kegiatan menghimpun informasi, membandingkan, mengategorikan, menganalisis, mengintegrasikan, mereorganisasikan bahan serta membuat simpulan-simpulan. Firman Allah dalam Qs. al-'Alaq/96:1, mengajak manusia menemukan hakikat kehidupan melalui iqra', yaitu membaca reflektif dengan mengkaji, menelaah, mengobservasi, dan membaca kitab suci. Allah memberikan catatan bahwa apa yang dikaji, ditelaah dan diobservasi itu harus ism rabbik, bermanfaat bagi kemanusiaan. Perintah iqra' 
yang diulang dalam ayat ke-3 surat yang sama menunjukkan membaca di samping harus diulang atau dilakukan hingga mencapai batas maksimal, juga mengisyaratkan mengulang-ulang bacaan akan menghasilkan pengetahuan dan wawasan baru dari yang dibacanya. Diduga, kemunculan para ilmuan dalam berbagai disiplin ilmu didukung upaya penemuan (discovery) mereka memaksimalkan diri dalam mempelajari bidang ilmunya. Kajian-kajian melalui penemuan tersebut melahirkan berbagai disiplin ilmu, seperti astronomi, astrologi, biologi, dan lainlain. (Karman, 2017:342).

\section{Self-Direct-Learning (Belajar Mandiri)}

Istilah direction mengacu pada kebutuhan pembelajar terhadap bantuan dari orang lain dalam proses pembelajaran dan menunjukkan kompetensi peserta didik dalam suatu materi pembelajaran. Peserta didik yang berkompetensi tinggi dan kebutuhan bantuan umum rendah akan menjadi peserta didik yang lebih independen. Peserta didik yang berkompetensi rendah dan berkebutuhan bantuan umum rendah membutuhkan arahan dalam tahap awal belajarnya.

Pembelajaran mandiri dilakukan dengan cara menyuruh peserta didik agar belajar sendiri baik di dalam maupun di luar kelas. Belajar mandiri, self-direct-learning, dalam beberapa literatur memiliki dua pengertian. Pertama, self teaching, pengajaran mandiri, yaitu para pembelajar mampu mengontrol mekanisme dan teknis mengajar diri mereka dalam subjek tertentu. Kedua, personal autonomy, otonomi pribadi. Personal autonomy yang oleh Candy disebut autodidaxy, autodidak, berarti mengontrol tujuan dan maksud belajar dan mengandaikan kepemilikan belajar. (Knowles, 1998:135; Rosidin, 2015:54-56). Menurut Knowles, mayoritas pendidik profesional menganggap dimensi paling 
a l-iltizam ,Vol.3, No.2, November 2018 penting dari self-direct-learning itu membina personal autonomy yang membuat peserta didik dapat menentukan arah pembelajarannya sendiri.

Grow (1991) menawarkan self-direct-learning yang situasional. Ia mengajukan empat tahap kemandirian belajar (learning autonomy) dan gaya mengajar yang sesuai dengan pembelajar. Keempat langkah dimaksud mencakup: (1) tahap pertama peserta didik posisinya bergantung, dependent, sedangkan pendidik posisinya sebagai pelatih, authority. Di tahap ini pembelajaran dilakukan dengan umpan balik, feedback, yang segera, latihan, drill, pengajaran informasional, dan lain-lain; (2) tahap kedua, peserta didik berposisi sebagai tertarik, interested, sedangkan pendidik sebagai pemandu, motivator. Di tahap ini pembelajaran dilakukan dengan pengajaran yang menginspi-rasi dan diskusi terpimpin, strategi pembelajaran berbasis tujuan, dan lain-lain; (3) tahap ketiga peserta didik berposisi sebagai pembelajar terlibat, involved sedangkan pendidik sebagai fasili-tator. Di tahap ini pembelajaran dilakukan dengan diskusi yang difasilitasi oleh pendidik yang berpartisipasi secara sama, seminar, kerja kelompok, dan lain-lain; dan (4) tahap keempat, peserta didik berposisi sebagai pembelajar mandiri, self directed sedangkan pendidik sebagai konsultan, delegator. Di tahap ini pembelajaran dilakukan masa latihan, kinerja individual, belajar kelompok mandiri, dan lain-lain. ((Knowles, 1998:136-137; Rosidin, 2015:56).) Model ini sekaligus menunjukkan relevansi peran pendidik dalam proses pembelajaran. Pendidik dalam konteks ini bertugas mengidentifikasi posisi learning autonomy peserta didik. Hasil identifikasi pendidik dijadikannya dalam menentukan peran paling sesuai untuk dilakukan selama proses pembelajaran. Namun, karena tidak semua 
a l-iltizam , Vol.3, No.2, November 2018 peserta didik memi-liki skill sama, self-direct-learning bersifat situasional. Pendidik dalam konteks ini perlu memertimbangkan kebutuhan peserta didik mencakup arahan (direction) dan bantuan (support). Pendidik harus mengetahui dimensi mana yang dibutuhkan oleh peserta didik dari dua kebutuhan tersebut.

Al-Qur'an 15 abad yang lalu telah menunjukkan strategi selfdirect-learning ini sebagaimana dapat dilihat dalam Qs. al-Baqarah/2: 31-33. Hal itu dapat dilihat dari redaksi, "wa 'allama Âdam al-asmâ' kullahâ" yang mengindikasikan Nabi Âdam as. --- sebelum dibimbing oleh Allah --- berposisi sebagai peserta didik yang bergantung karena tidak memiliki pengetahuan. Allah, sebagai pendidik, berposisi sebagai pemegang otoritas (authority) karena pembelajaran berasal dari inisiatif-Nya. Pengetahuan Nabi Âdam as. dalam jangka waktu tertentu, frasa summa, berkembang melalui pengalamannya sehingga layak dievaluasi di hadapan malaikat, summa 'arad\{ahum 'alâ al-malâ'ikah. Redaksi ini mengindikasikan Allah sebagai pembimbing, bukan lagi pendidik yang, peserta didiknya Nabi 'Âdam as. dan malaikat.

Teknik yang digunakan dalam pembelajaran tersebut, meminjam istilah 'Alî Ahmad Madkûr (:244), al-munâqasyah al-muwajjahah, diskusi terpimpin yang dapat dilihat dari redaksi faqâla anbi' ûnî biasmâ' $i$ hâ'ulâ'i, sebutkanlah kepada-Ku nama-nama (simbol) itu. Malaikat dalam diskusi tersebut tidak mampu menunjukkan jawaban yang dikehendaki karena Allah tidak memfasilitasi malaikat sehingga mereka disebut sebagai makhluk statis, tidak kreatif-inovatif. Ini berbeda dengan Nabi Âdam as. yang didesain sebagai makhluk dinamis, kreatifinovatif seperti dapat dipahami dari frasa 'allama tadi. 
Perkembangan pengetahuan Nabi Âdam as. menjadi peserta didik mandiri (directed) dibuktikan dengan permintaan Allah kepada Nabi Âdam as. membuktikan perkembangan pengalamannya ----- melalui pengembangan penalaran. Hal ini dapat dilihat dari redaksi yang digunakan Allah dalam ayat-ayat tersebut; ketika berbicara kepada malaikat Allah menggunakan redaksi pertanyaan, question, istifham, sedangkan kepada Nabi Âdam as. menggunakan redaksi perintah, command, al-amr. Ini menunjukkan peralihan fungsi Allah swt. sebagai pendidik menjadi delegator (delegasi). Nabi Âdam as. yang tadinya sebagai dependent, telah berposisi sebagai peserta didik mandiri (directed) sekaligus memiliki kapasitas self-teaching dan personal authority.

\section{Kontribusi Al-Qur'an dalam Pengembangan Pembelajaran Aktif}

Ada dua hal yang dapat digunakan untuk menganalisis kontribusi Al-Qur'an dalam pengembangan pembelajaran aktif di lembaga-lembaga pendidikan. Pertama, kontribusi teoretis. Al-Qur'an telah menunjukkan dalam berbagai ayatnya kecenderungan pembelajaran yang oleh para ahli dikategorikan pada behaviorisme, humanisme dan konstruktivisme. Firman Allah dalam Qs. al-Baqarah/2:33 dan Qs. al-'Alaq/96:1, misalnya, secara teoretis menunjukkan pembelajaran konstruktivisme yang oleh pendukungnya dikuatkan dengan konstruktivistik. Ini berarti pembelajaran dengan menggunakan metode drill dapat dikelompokkan dalam pembelajaran konstruktivisme. Namun, bagi para pendukung sebaliknya, drill lebih cenderung pada metode pembelajaran yang berorientasi behavioristik.

Kategorisasi behaviorisme dan konstruktivisme bukan pilihan absolut, terutama jika dikaitkan dengan kurikulum yang disepakati. 
Kurikulum apapun yang digunakan tidak dapat menganut salah satu teori pembelajaran secara utuh dengan mengabaikan teori dasar lainnya sehingga teori tersebut dapat saling melengkapi. Namun, porsi maupun kecenderungan terhadap satu teori belajar tidak dapat dihindarkan, karenaa diantara teori-teori tersebut terdapat beberapa prinsip-prinsip yang dipandang bertentangan karena teori tersebut disusun dengan asumsi yang berbeda. Dengan kata lain, pemilihan pendekatan/teori belajar bukanlah memilih dalam alternatif baik atau tidak baik, melainkan ada atau tidak kesesuaian dengan berbagai pertimbangan kelayakannya. Ada beberapa kelebihan dan kelemahan dari modelmodel pendekatan pembelajaran tersebut.

Kedua, kontribusi praktis. Kontribusi praktis dapat dilihat dari seberapa jauh para pendidik melakukan kreativitas dan inovasi pembelajaran melalui berbagai uji coba. Menurut Yulaelawati (2004), berdasarkan karakteirtik dari teori behaviouristik, kognitif, dan konstruktivistik, ahli melalui berbagai penelitiannya cenderung menyarankan teori konstruktivistik lebih layak untuk diterapkan secara dominan. Hal ini beralasan jika dikaitkan dengan karakteristik sumber daya manusia (SDM) yang dibutuhkan di era global.

Inovasi pembelajaran mendasarkan diri pada paradigma konstruktivistik. Pembelajaran inovatif yang berlandaskan paradigma konstruktivistik membantu peserta didik menginternalisasi, membentuk kembali, atau mentransformasi informasi baru. Transformasi menurut Gardner (1991) terjadi melalui kreasi pemahaman baru yang merupakan hasil dari kemunculan struktur kognitif baru. Pemahaman yang mendalam terjadi ketika hadir informasi baru yang mendorong kemunculan atau menaikkan struktur kognitif yang memungkinkan 
a l-iltizam ,Vol.3, No.2, November 2018

para peserta didik memikirkan kembali ide-ide mereka sebelumnya. Para peserta didik dalam seting kelas konstruktivistik, bertanggung jawab terhadap belajarnya, menjadi pemikir yang otonom, mengembangkan konsep terintegrasi, mengembangkan pertanyaan yang menantang, dan menemukan jawabannya secara mandiri (Brook \& Brook, 1993; Duit, 1996; Savery \& Duffy, 1996). Tujuh nilai utama konstruktivisme, yaitu: kolaborasi, otonomi individu, generativitas, reflektivitas, keaktifan, relevansi diri, dan pluralisme. Nilai-nilai tersebut menyediakan peluang kepada peserta didik dalam pencapaian pemahaman secara mendalam.

Setting pengajaran konstruktivistik yang mendorong konstruksi pengetahuan secara aktif memiliki beberapa ciri: (1) menyediakan peluang kepada peserta didik belajar dari tujuan yang ditetapkan dan mengembangkan ide-ide secara lebih luas; (2) mendukung kemandirian peserta didik belajar dan berdiskusi, membuat hubungan, merumuskan kembali ide-ide, dan menarik simpulan sendiri; (3) sharing dengan peserta didik mengenai arti penting pesan bahwa dunia tempat yang kompleks, tempat terdapat pandangan yang multi dan kebenaran sering merupakan hasil interpretasi; (4) menempatkan pembelajaran berpusat pada peserta didik dan penilaian yang mampu mencerminkan berpikir divergen peserta didik. Revitalisasi pembelajaran dengan menerapkan pendekatan konstruktivisme diyakini memberi peluang lebih besar untuk menunjang keberhasilan pendidikan.

Pembelajaran yang berpedoman pada konstruktivistik dalam metode drill dapat dilihat dalam beberapa hal.

1. Pengunaan pembelajaran inkuiri dilakukan dengan cara mengajar kepada sekelompok peserta didik untuk bekerja sama dan me- 
a l-iltizam , Vol.3, No.2, November 2018 mecahkan masalah dengan cara mengerjakan tugas yang diberikan kepada mereka untuk menyapai tujuan yang dikehendaki. Teknik pembelajaran ini menempatkan pendidik sebagai fasilitator dan memotivasi peserta didik untuk menunjukkan kreativitas dan inovasinya. Teknik inkuiri memiliki kelebihan dengan memberikan kesempatan kepada peserta didik untuk menggunakannya, baik bertanya maupun membahas suatu masalah sehingga lebih intensif melakukan penyelidikan dan berpartisipasi dalam berdiskusi. Kelemahan teknik ini tampak kurang ada keseragaman kemampuan peserta didik sehingga hanya mereka yang mampu sajalah yang aktif sedangkan yang lain menjadi pendengar pasif.

2. Kelebihan teknik discoveri ini dapat mengembangkan kesiapan mental peserta didik seperti mengamati, mengerti, menglasifikasikan, membuat asumsi, menjelaskan menugkur, dan membuat konklusi. Teknik diskoveri juga dapat membangkitkan gairah belajar karena termotivasi dan ada kepercayaan diri. Sementara itu, kelemahan teknik diskoveri tampak bahwa peserta didik tidak semua memiliki kesiapan mental sehingga kurang beran bertindak dan tidak banyak memberikan peluang untuk berpikir secara intensif.

3. Beberapa prosedur dalam penggunaan teknik belajar dalam pembelajaran mandiri, yaitu: (1) menggali minat dan kompetensi peserta didik dengan berbagai instrumen untuk dasar belajar sendiri, (2) bahan dan pengalaman disediakan di sekitar minat dan kemampuan peserta didik, (3) perlu ada kontrak dengan peserta didik tentang hal-hal yang perlu dilakukan, (4) keterampilan yang perlu dicek mencakup cara mencatat, menggunakan perpustakaan, cara melapor lisan atau tulisan, (5) memberi waktu yang memadai, 
a l-iltizam , Vol.3, No.2, November 2018

membantu peserta didik sesuai dengan kebutuhannya, menolong menilai kemajuan peserta didik dengan memeriksa catatannya, mengadakan diskusi antarpeserta didik untuk bertukar pengalaman dan merencanakan belajar mandiri.

\section{Simpulan}

Meode drill dalam al-Qur'an mencakup hal yang dapat membangun kreativitas dalam pembelajaran. Al-Qur'an telah menunjukkan dua kontribusinya dalam pembelajaran yaitu kontribusi teoretis dan kontribusi praktis. Kontribusi teoretis ditunjukkan dengan penjelasannya bahwa al-Qur'an telah memberikan semangat pemberdayaan nalar sehingga melahirkan kreativitas dan inovasi dalam pembelajaran. Kontribusi praktis ditunjukkan dengan penjelasannya bahwa al-Qur'an telah mengembangkan kreativitas dan inovasi dalam kegiatan pembelajaran melalui pemberdayaan nalar sehingga melahirkan pembelajaran konstruktivistik.

\section{DAFTAR PUSTAKA}

Ahmad Tafsir. (1995). Metodologi Pengajaran Agama Islam.

[1] Bandung: Remaja Rosdakarya.

[2] Pustaka Setia.

Hamdani. (2011).Strategi Belajar Mengajar. Bandung: Isfahânî. Muhammad al-Râgib al-. (t.t.). Mu'jam Mufradât [3] ALfâz Al-Qur'ân. Beirût: Dâr al-Fikr.

Juniati, Erlyn. (2017). "Peningkatan Hasil Belajar [4] Matematika melalui Metode Drill dan Diskusi Kelompok pada Siswa Kelas VI SD. Scholaria": Jurnal Pendidkan dan 
Kebudayaan, $\quad 7 \quad$ (3), 283-291 DOI: https://doi.org/10.24246/scholaria.2017.v7.i3283-291.

Kaplan, Abraham. (1964). The Conduct of Inquiry. Seranton

[5] Pensyl-pannia: Candeler Publishing Company.

Karman. (2016). "Tatwîr Namûdaj al-'Ulûm al-Islâmiyyah fî̀

[6] Jâmi'ah Ambun al-Islâmiyah al-Hukûmiyah" dalam Jurnal Pendidikan Islam, Volume 2. Nomor 3, Desember. h. 497514.

Karman. (2017). Tafsir Ayat-ayat Pendidikan. Bogor:

[7] Hilliana Press.

Kezia Irene Astuningtias, dkk. (2017). "Penerapan Metode

[8] Drill untuk Mening-katkan Hasil Belajar Kognitif Siswa Kelas IX Materi Statistika di SMPN Kristen Rantepao" dalam JOHME: Journal of Holystic Mathematics Education. V1. 1. No.1. Dec. h. 53-59.

Knowles, Malcom Sherperd. (998).The Adult Learner: The

[9] Definite Classic in Adult Education and Human Resources Development, Houston: Gulf Publishing Company.

Mahmud Arif. (2015).Tafsir Pendidikan: Makna Edukasi al-

[10] Qur'an dan Aktualisasi Pembelajarannya, Yogyakarta: Ombak.

Marâgî, Ahmad Mustafâ al-. (1998). Tafsîr al-Marâgî, Juz

[11] IX. Beirût: Dâr al-Fikr.

[12] Beirût: Dâr al-Fikr.

Roestiyah. (2008). Strategi Belajar Mengajar. Jakarta:

[13] Rineka Cipta.

Rosidin. (2015).Metodologi Tafsir Tarbawi. Cet. I; Jakarta:

[14] Amzah.

Sagala. (2013). Konsep dan Makna Pembelajaran. Bandung:

[15] Alfabeta. 